\title{
HISTOCHEMICAL INVESTIGATION ON ARCHIDENDRON BUBALINUM (JACK) NIELSEN.) FROM LAMPUNG, SUMATERA, INDONESIA
}

\author{
HESTI RIASARI ${ }^{1,2 *}$, RIKA HARTATI ${ }^{1}$, KUSNANDAR ANGGADIREDJA $^{1}$, SUKRASNO $^{1}$
}

1Department of Pharmaceutical Biology, School of Pharmacy, Institut Teknologi Bandung, Jl Ganesha 10, Bandung 40132, West Java, Indonesia, 'Department of Pharmaceutical Biology, Indonesia School of Pharmacy Jl. Soekarno Hatta 354, Bandung 40266, West Java, Indonesia

*Email: hestiriasari@stfi.ac.id

Received: 14 Aug 2020, Revised and Accepted: 04 Oct 2020

\begin{abstract}
Objective: This study was to describe the histochemical and morpho-anatomical of kabau seeds originating from Lampung, Sumatra Indonesia.
\end{abstract}

Methods: Microscopic anatomical analysis of kabau seeds was carried out on the parts of kabau seeds with an incision as thick as $100 \mu$ m. The sample was placed on a glass object and aquadest, glycerin and choral hydrate were added and then covered with a glass cover, then observed under the light microscope equipped with digital camera, and analysis using the S-Viewer program. Histochemical tests are carried out with cross sections, which are colored with the following: Lugol iodine solution; ferric chloride; dragendr of; ninhydrin; $\mathrm{K}_{2} \mathrm{Cr}_{2} \mathrm{O}_{7}$.

Results: Macroscopic characteristics, neatly arranged cylindrical kabau seeds consisting of five to six seeds on each pod. Yellowish-white kabau seeds are covered in a black seed coat, have a distinctive odor like jengkol or jering, have a slightly bittersweetness and a soft texture. The size of kabau seeds is $2 \mathrm{~cm}$ in length and $1.5 \mathrm{~cm}$ in diameter. Microscopic results on kabau seeds, an incision in choral hydrate showed visible parts of the epicarpium, pericarpium contained oil sacs and cell nuclei, and endosperm in each part of the sac contained starch grains and oil sac bags that gave off odors to the head, incisions in the drops of aqua dest almost the same as choral hydrate except that the starch grains are more clearly visible and an average diameter of 5,176 $\mu \mathrm{m}$ starch can be calculated.

Conclusion: Histochemical reaction in the Kabau seed incision gave positive results on tannins in the endosperm, positive results for amino acids in the endosperm of purple rice, positive for alkaloids in the epicardium and pericarpium parts; black color throughout the epicardium, pericarpium and endosperm indicates a lot of starch is contained; and there are polyphenols in the endosperm oil sac.

Keywords: Archidendron bubalinum (Jack) Nielsen., Histochemical, Macroscopic

(C) 2021 The Authors. Published by Innovare Academic Sciences Pvt Ltd. This is an open access article under the CC BYlicense (https://creativecommons.org/licenses/by/4.0/) DOI: https://dx.doi.org/10.22159/ijap.2021.v13s3.02 Journal homepage: https://innovareacademics.in/journals/index.php/ijap

\section{INTRODUCTION}

Kabau is a familia with jengkol, which is included in the Fabaceae, where the Fabaceae has three sub-tribus, namely Faboideae, Caesalpinoideae, Mimosoideae. Kabau belongs to the Mimosoideae subclass, the Archidendron clan, with the name of the type Archidendron bubalinum (Jack) Nielsen, its synonym name is Pithecellobilum bubalinum (Jack) Benth (The PlantList). Kabau or commonly called jaling are found on the island of Sumatra. Kabau naturally grows wild in lowland primary and secondary forests, but the large number of people changing rubber forests to oil palm plantations has an impact on the diminishing kabau population [1]. Kabau (Archidendron bubalinum (Jack) I. C. Nielsen] is a close relative of Jengkol (Archidendron jiringa (Jack) I. C. Nielsen), naturally grows in Thailand, the Malay Peninsula and Sumatra. Kabau has different local names, for example kabau (Jambi, Palembang, Riau), jering utan (Riau), kabeu (Bengkulu), jering kabau (West Sumatra), gnats (Lampung), kerdas or squirrel rings (Malaysia) and nieng-nok (Thailand) [2-5].

The shape and anatomy of the kabau from the shape of the stems and rakila young kabau leaves have characteristic red purplish or green. The diameter of the pods ranges from 1.3 to $2.7 \mathrm{~cm}, 5-10 \mathrm{~cm}$ long. The outer surface is green to yellowish-green with smooth or wrinkled skin, bald or hairy until dreadlocks. The shape of the fruit or pods varies, between cylindrical or flat, straight or curved. Cylindrical pod shape, rounded base, notched tip, rounded seed; while the flat pods form the base of the menusus, the tip is rounded, the seeds push across the latitude. Seed size varies, small seeds have a diameter of $<2 \mathrm{~cm}$, and large seeds have a diameter of $\geq 2 \mathrm{~cm}$. Seed size variation is not influenced by the shape of the pods, because in the form of cylindrical and flat pods, each has a large and small seed size [1].

Jambi people use kabau seeds as a diabetes drug. The ripe seeds are dried by roasting, then finely ground. Kabau seeds that have been mashed are then dissolved in water and taken twice a day. Meanwhile, in other species, A. jiringa seed infusion with a dose of $25.21 \pm 2.28 \mathrm{mg} / \mathrm{dl}$ can reduce blood sugar levels in mice [6]. Therefore, members of the Archidendron tribes can be developed as an anti-diabetes drug.

Information about secondary metabolites contained in the kabau is still very little, therefore microscopic and histochemical carried out on the kabau seeds to determine the distribution of compounds in the tissue of kabau seeds so that it can facilitate the characterization of phytochemical compounds that can contribute to antidiabetic activity and initiated a study on histochemistry of kabau seeds found in Lampung. Histochemical testing on kabau seeds is not yet available in the literature; thus, there is new knowledge about histochemical studies on kabau seeds.

\section{MATERIALS AND METHODS}

\section{Plant material}

Kabau seeds (Archidendron bubalinum (Jack) Nielsen), Fabaceae were obtained in January 2018 from Bumi Baru village, Blambangan Umpu District, Waykanan Regency, Lampung, Sumatra Island, Indonesia. The collection of plant material was determined at the Indonesian Institute of Sciences, Biological Research Center, LIPI Bogor, number: 408/IPH. I.01/If.07/II/2018 on February 13, 2018; under the responsibility of the Head of Botany for the Biology-LIPI Research Center, Dr. Joeni Setijo Rahajoe.

\section{Macroscopic and microscopic characteristics}

Macroscopic characterization of fresh and dried kabau seeds viewed in shape, size, smell and taste. For microscopic anatomy of kabau seeds performed under light microscopy (LM). Microscopic anatomical analysis of kabau seeds was carried out on the parts of the kabau seeds by making an incision as thick as $100 \mu \mathrm{m}$; then the 
incision was placed on a glass object and aquadest, glycerin and cloral hydrate were added then covered with a glass cover then observed under a light microscope. In addition to fresh seed plant samples. The semipermanent and histochemical test slide images were obtained with an Olypmpus CX21LED light microscope equipped with a Model SXY-I50L digital camera, and analysis using the S-Viewer program.

\section{Histochemical}

Histochemical tests are carried out with cross-sections, which are colored with the following reagents. Lugol iodine solution to reveal the presence of starch granules, ferric chloride for polyphenols [7-
10], Dragendroff reagent for the detection of alkaloid compounds $[11,12]$, ninhydrin for the detection of amino acids [13], $\mathrm{K}_{2} \mathrm{Cr}_{2} \mathrm{O}_{7}$ (potassium dichromate) for detection of tannins/phenolates [14].

\section{RESULTS AND DISCUSSION}

The result of macroscopic characteristics, neatly arranged cylindrical kabau seeds consisting of five to six seeds on each pod. Yellowish-white kabau seeds are covered in a black seed coat, have a distinctive odor like jengkol, have a slightly bittersweetness and a soft texture. The size of kabau seeds is $2 \mathrm{~cm}$ in length, $1.5 \mathrm{~cm}$ in diameter, and Institutions or cotyledons (seed germination) can be seen in fig. 1 and 2 .

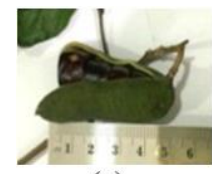

(a)

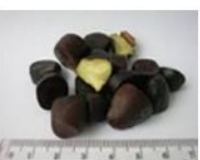

(b)

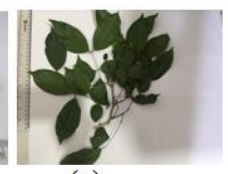

(c)

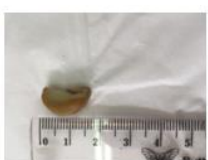

(d)

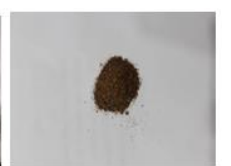

(e)

Fig. 1: (a). Kabau Fruit; (b) Kabau; Seeds (c) Kabau Leaves; (d) Kabau seeds without the skin; e) Kabau seeds powder

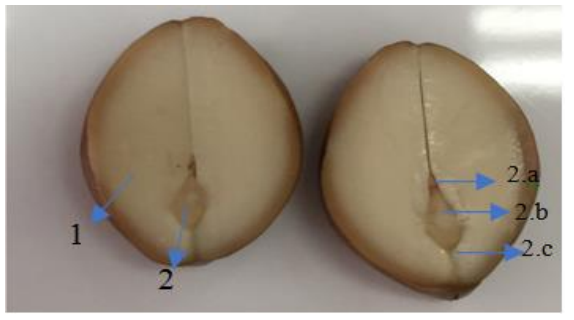

Fig. 2: 1. White Institution/albumen; 2. Institution/seed germination; 2. a Cotyledon; 2. b Cotyledons; 2. c Radicula

Fig. 2 is the result of a radial incision in kabau seeds to see macroscopically the parts of cotyledons and white institutions, white institutions/albumen containing food reserves for sprout growth [15]. There are cotyledons which are plants that will later become leaves and stems, while the radicula is a plant that will become the root. In this section, microscopes were carried out at institutions and cotyreneons at magnification 100x, can be seen in fig. 3 .

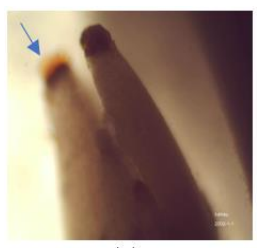

(a)

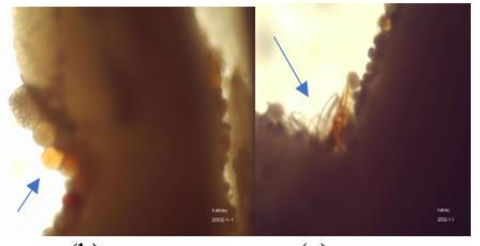

(b)

(c)
Fig. 3: (a) Cotyledons, (b) Cotyledons, (c) Radicula

Microscopic results on kabau seeds were carried out through histochemical tests, where kabau seeds were sliced to a thickness of $1 \mu \mathrm{m}$, each incision in the choral hydrate was seen with epicarpium, pericarpium containing oil sacs and cell nuclei, and endosperm in each part of the sac. There are starch grains and oil sacs which give off a scent; the incision in the drops of aquadest is almost the same as chloral hydrate, except that the starch grains appear more clearly and can calculate the average diameter of starch grains. Microscopic characteristics of the mangrove seeds can be seen in fig. 4 and fig. 5.

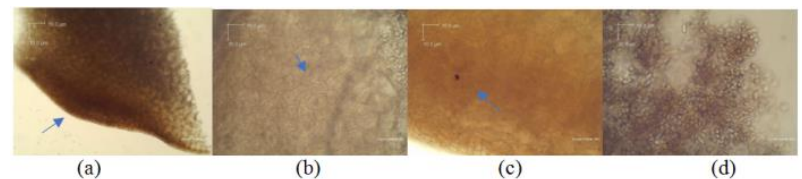

Fig. 4: Kabau seed incision with choral hydrate (a) epicarpium, (b) pericarpium, (c) pericarpium with a nucleus, (d) endosperm with starch grains

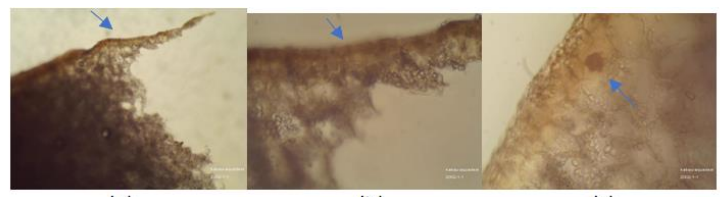

(a)

(b)

(c)

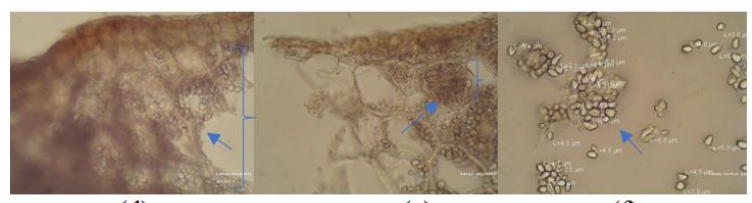

(d)

(e)

(f)

Fig. 5: (a) Transverse incision of kabau seeds plus aquadest (40x magnification); (b) epicarpium (100x magnification); (c) pericarpium with a nucleus (magnification 100x); (d) Endosperm with starch grains in Amyloplast (magnification 100x); (e) Amyloplast containing starch grains (magnification 100x); (f) Starch Grain (Magnification of 100x) 
Histochemical results on kabau seed incision with 5\% addition of copper acetate to see the distribution of terpenoid secondary metabolites in kabau seed incision, after being observed under a microscope, the distribution of terpenoids on the part of pericarpium which reacts with the $5 \%$ acetate copper catalyst retained for 1 hour gives positive color reaction yellow or brownish yellow [16] can be seen in fig. 6 .

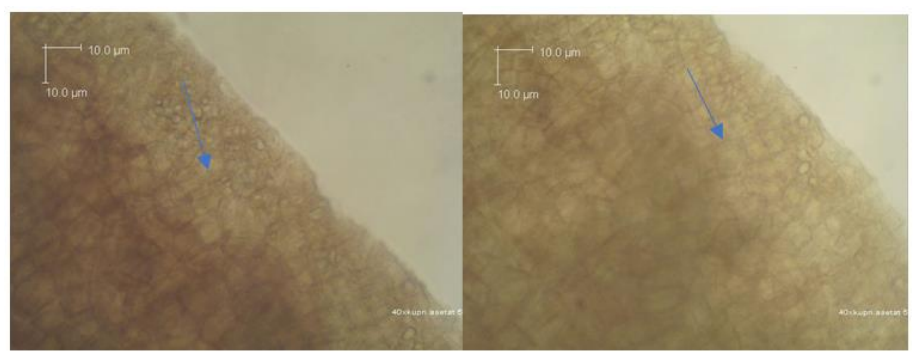

Fig. 6: Positive reaction of kabau seed incision when reacted with $5 \%$ cupric acid in the pericarpium portion (magnification (400x)

Histochemical results in Kabau seed incision with the addition of dragendrof recording reacted for 2-4 min then rinsed with aquadest gave a positive reaction to brownish orange color [11,
12] (on the pericarpium and endosperm shows that the distribution of alkaloid compounds is found in many the section, can be seen in fig. 7 .

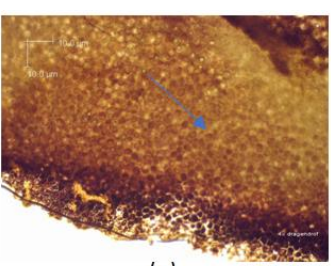

(a)

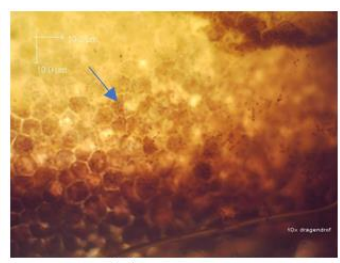

(b)

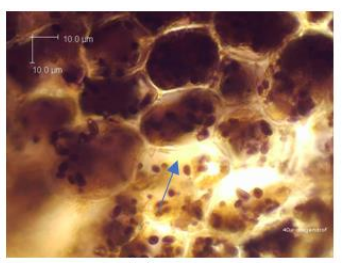

(c)

Fig. 7: (a) positive reaction on the pericarpium portion (40x magnification); (b) Positive reactions on the pericarpium and endosperm portion (100x magnification); (c) Positive reaction on the endosperm with starch grains in amyloplast (400x magnification)

Histochemical results on the incision of kabau seeds with the addition of ninhydrin heated for 1-2 min showed positive reaction in purple,[13] showing that there were amino acid or protein compounds in all parts of epicarpium, pericarpium and endosperm with starch grains in amyloplast. The results can be seen in fig. 8.

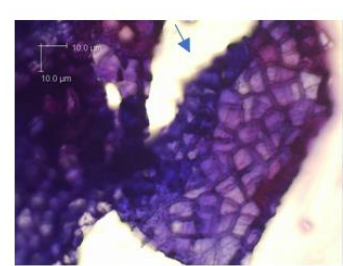

(a)

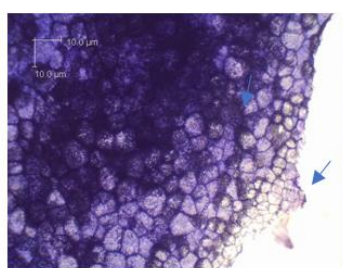

(b)

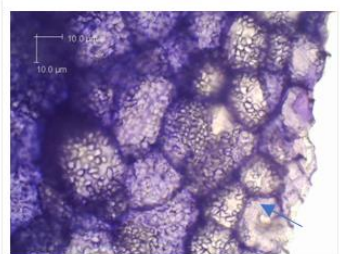

(c)

Fig. 8: (a) positive reaction on epicarpium, pericarpium, endosperm (40x magnification); (b) Positive reactions on the epicarpium and pericarpium portions (100x magnification); (c) Positive reaction on the endosperm with amyloplast (400x magnification)

Histochemical results on the incision of kabau seeds with the addition of Lugol were allowed to stand for $5 \mathrm{~min}$. Brownish black positive reaction occurs in the endosperm with starch grains that are in amyloplast, which can be seen in fig. 9.

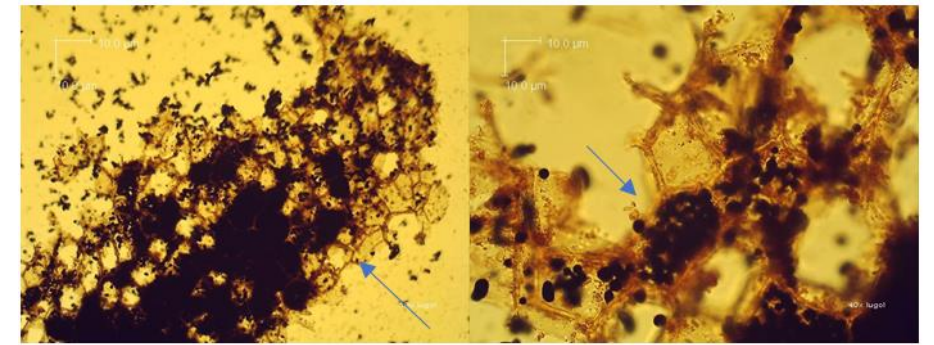

(A)
(B)

Fig. 9: (A) positive reaction on the endosperm with starch in amyloplast (magnification 100x); (B) starch grains in amyloplast (400x magnification) 
Histochemical results on the incision of kabau seeds with the addition of $\mathrm{K}_{2} \mathrm{Cr}_{2} \mathrm{O}_{7}$ were allowed to stand for $5 \mathrm{~min}$ to see the tannin/phenolic compound [14]. A positive reaction is present in the oil sacs at the endosperm, can be seen in fig. 10.

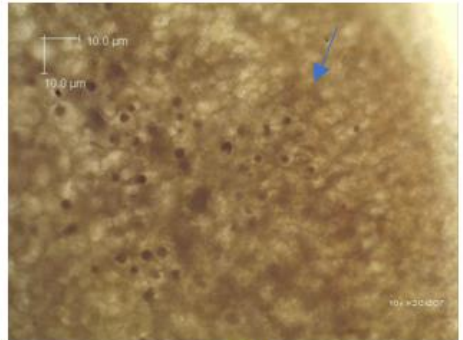

(A)

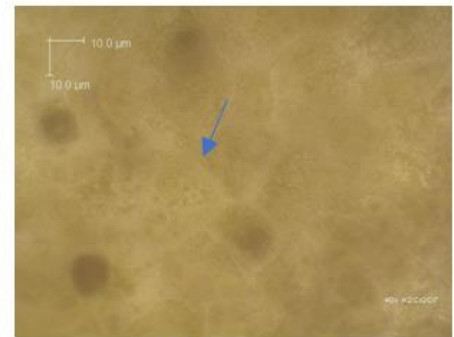

(B)

Fig. 10: (A) positive reaction on the endosperm part that contains the oil sac (100x magnification); (B) Oil bag (400x magnification)

Histochemical results on kabau seed incision with the addition of $\mathrm{FeCl}_{3}$, allowed to stand for $5 \mathrm{~min}$; there was a positive reaction giving a blackish green color to all parts of the epicardium, pericarpium and endosperm layers, can be seen in fig. 11.

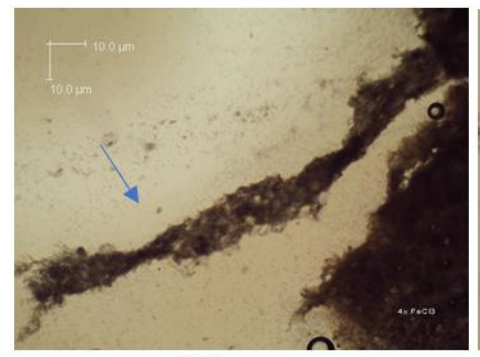

(A)

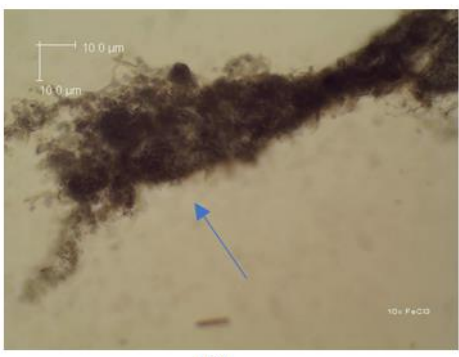

(B)

Fig. 11: Positive reaction of kabau seed incision when reacted with $\mathrm{FeCl}_{3}$, giving positive reaction to epicarpium, pericarpium and endosperm, (A) at 40x magnification and (B) at magnification (100x)

\section{CONCLUSION}

Morphological analysis, both macroscopic and microscopic on kabau seeds is to identify species of Archidendron bubalinum species originating from Lampung. The morpho-anatomical character of the kabau seeds is cylindrical in a neatly arranged structure consisting of five to six seeds on each pod. smells like jengkol, has a slightly bitter sweetness and soft texture. Kabau seeds are of an average length of $2 \mathrm{~cm}, 1.5 \mathrm{~cm}$ in diameter, and Institutions or cotyledons (seed germination), in microscopic analysis, kabau seeds consist of 3 layers, namely epicarpium, pericarpium and endosperm containing amyloplast with starch and sac-oil bag. Microscopically there are cotyledons and cotyledons. Histochemical analysis of cabbage seeds contained fonalate compounds, tannins, alkaloids, terpenoids, proteins/amino acids, starches, which were distributed differently in the parts of kabau seeds, making it easier to identify compounds that contributed to the activity of kabau seeds.

\section{FUNDING}

I as the author would like to thank the Ministry of Research and Technology of Higher Education for funding the doctoral dissertation research through a doctoral dissertation research grant in 2019-2020.

\section{AUTHORS CONTRIBUTIONS}

All the authors contributed equally.

\section{CONFLICT OF INTERESTS}

Declared none

\section{REFERENCES}

1. Komariah D, Hartana A. Variasi morfologi kabau (Archidendron bubalinum) dan pemanfaatannya di sumatera. Floribunda 2016;5:157-63.
2. Heyne K. De nuttige planten van nederland-sch Indie. Buitenzorg (ID): Departement LNH Ned. Indie; 1927.

3. Nielsen IC. Mimosaceae (Leguminosae-mimosoideae). Flora Malesiana. Series I. Leyden (NL): Flora Malesiana Foundation; 1992. p. 11.

4. Lim TK. Edible medicinal and non-medicinal plants: Fruits. Vol. 2. New York (US): Springer; 2012.

5. Ghazalli MN, Masrom H, Omar Y, Farhana AS. A preliminary flora survey in Gunung Kajang, Pulau Tioman, Pahang Darul Makmur, Malaysia. Malays. Appl Biol 2014;43:17-23.

6. Retno S, Sudrajat, Sudiastuti. Efektivitas infusa biji jengkol (Archidendron jiringa Jack) dan daun Vernonia amygdalina delile terhadap penurunan kadar gula darah mencit (Mus musculus) yang diinduksi aloksan. Prosiding Seminar Sains dan Teknologi FMIPA Unmul Periode Maret 2016. Samarinda, Indonesia; 2013.

7. Johansen DA. Plant microtechnique. McGraw-Hill, New York; 1940.

8. Berlyn GP, Miksche JP, John ES. Botanical microtechnique and cytochemistry-technique plant anatomy. Iowa State University Press: Ames, Iowa; 1976.

9. Kraus JE, Arduin M. Manual basico de metodos em morfologia vegetal. Seropedica. RJ, Brasil: EDUR; 1997.

10. Formulario Nacional Da Farmacopeia Brasileira. Ministerio da Saude. Agencia Nacional de Vigilancia Sanitaria. 2 ed. Brasília: Anvisa; 2012.

11. Wagner H, Bladt S. Plant drug analisys: a thin layer chromatography atlas. Second Ed. 350. New York. Springer; 1996.

12. Jing H, Liu J, Liu H, Xin H. Histochemical investigation and kinds of alkaloids in leaves of different developmental stages in Thymus quinquecostatus. Scientific World J 2014;839548. https://doi.org/10.1155/2014/839548. 
13. Hart H, Craine LE, Hart DJ. Kimia organik edisi kesebelas. Erlangga. Jakarta; 2003.

14. Gabe M. Techniques histologiques. Masson, Paris; 1968.

15. Gembong T. Taksonomi Tumbuhan. Yogyakarta: UGM; 2009.
16. Harborne JB. Metode fitokimia: penuntun cara modern menganalisis tumbuhan edisi kedua, diterjemahkan oleh padmawinata dan soediro, bandung, ITB University Press; 1996. p. 42-61. 